\title{
Influence of Limestone Dust on No-Fines Concrete
}

\author{
Mohammed Saquib Ayubi ${ }^{1}$, Mohd Tabrez Ahmed ${ }^{2}$ \\ ${ }^{I}$ (Department Of Civil Engineering, Lords Institute Of Engineering And Technology, India) \\ ${ }^{2}$ (Department Of Civil Engineering, Lords Institute Of Engineering And Technology, India)
}

\begin{abstract}
This paper presents experimental study on the potential use of limestone dust for producing a lightweight composite material some of physical properties of concrete material having various levels Limestone Powder Waste (LPW) in No-Fines concrete material is investigated. The obtained compressive strength, flexural strength, split tensile strength, unit weight satisfy the relevant Indian standards. The result shows the effect of high level replacement of Limestone Powder Waste (LPW). Recycling of unmanaged Limestone Powder Waste ( $L P W)$ as new brick material supplements appears to be the solution of environmental problems but also the problem of high cost.
\end{abstract}

\section{Introduction}

The increase in usage of environmental friendly, lightweight construction material in building material industry is to be investigated to know how it can be beneficent to the environment because of a large demand has been placed for building material in construction, the scarcity of building material have forced civil engineer to convert waste to useful construction material. The Limestone Powder Waste (LPW) utilized in this project are available widely in large amounts. This project shows some physical and mechanical properties of brick having different percentages of LPW. Most wastes used in this project are disposed and dumped in open areas. It is a big problem for industries for the disposal of Limestone Powder Waste (LPW). It is a worldwide environmental disposal problem therefore; the solution of this problem is usage of Limestone Powder Waste (LPW) in commercial by producing it in making Limestone Powder Waste (LPW) induced No-Fines Concrete. Limestone Powder Waste (LPW) in No-Fines Concrete is used because No-Fines Concrete has porosity in it. It has no fine aggregate in it. It has $25 \%$ of voids which results in high porosity concrete material. The blocks of limestone are cutted by chain saw, diamond wire and diamond saw and blocks are cut in smaller sizes to use as building material. The crushed limestone production results in approx 20\% Limestone Powder Waste (LPW). The Limestone Powder Waste (LPW) of 18 million tons in Greece, 21.2 million tons in UK and 30 million tons in Turkey is produced. Disposal of Limestone Powder Waste (LPW) causes environmental problem and pollution. It contaminants in air with storms in winter season and at last causes health problems, specifically asthma. The aim is to use industrial waste in building material LPW is used in No-Fines Concrete to use as a substitute for brick material. We are going to use No-Fines Concrete as per IS code 12727:1989. We are going to increase the Limestone Powder Waste (LPW) by 5\% in every variation of No-Fines concrete block and simultaneously decreasing the cement by 5\% in variations of block. Using Limestone Powder Waste (LPW) as a substitute for cement in No-Fines concrete block in its natural form has produced, economical, lighter and environment friendly new cement material. This project has studied the properties of this new concrete block material, which has different variations of Limestone Powder Waste (LPW) percentages and cement as binder and water. The replacement of Limestone Powder Waste (LPW) in No-Fines Concrete cement in tested samples unit weight has reduced by about (200-300gms). It is (pervious concrete but with LPW).

\section{Research Methodology}

Materials:-

Limestone Powder Waste (LPW) used in No-Fines Concrete is produces during cutting of limestone blocks. The results of chemical and physical proportions of Limestone Powder Waste (LPW) and cement are given in Table.1. Cement used in the project is Ordinary Portland Cement of 53-Grade of Birla Shakti Company produced in the companies cement mill. Top water is used in this project of $\mathrm{pH} 6.5$.

Mixing \& Fabrication of Brick:-

Table 1

(Properties of Limestone Powder Waste \& Cement)

\begin{tabular}{|l|l|l|}
\hline Properties & LPW \% by mass & Cement \% by mass \\
\hline $\mathrm{SiO} 2(\%)$ & 0.26 & 19.20 \\
\hline $\mathrm{CaO}(\%)$ & 56.19 & 52.00 \\
\hline $\mathrm{MgO}(\%)$ & 0 & 1.00 \\
\hline $\mathrm{Na} 2 \mathrm{O}(\%)$ & 0 & 0 \\
\hline $\mathrm{K} 2 \mathrm{O}(\%)$ & 0 & 0.27 \\
\hline $\mathrm{A} 12 \mathrm{O} 3(\%)$ & 0.25 & 3.70 \\
\hline
\end{tabular}

DOI: $10.9790 / 1684-1402081216$

www.iosrjournals.org

12 | Page 


\begin{tabular}{|l|l|l|}
\hline So3 & 0 & 2.80 \\
\hline Fe2O3 & 0.30 & 0.16 \\
\hline $\mathrm{pH}$ & - & - \\
\hline Loss of Ignition & 42.65 & 8.20 \\
\hline Density & 2.67 & 3.00 \\
\hline Compressive strength for 28 days (MPa) & & 53 \\
\hline
\end{tabular}

\section{Limestone Powder}

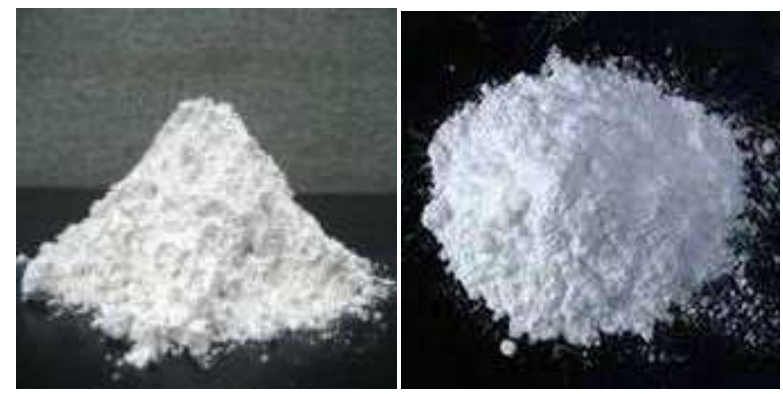

The water proportion in the mixes is taken 0.40 as constant as per IS code to No-Fines Concrete but the cement proportion is decreasing by $5 \%$ in every variation In this mixing process of samples, Limestone Powder Waste (LPW) coarse aggregate and cement contents are placed in concrete mixer. The coarse aggregate used is (1020mm) in the No-Fines Concrete. As per IS code 12727:1989

Table 2

\begin{tabular}{|l|l|l|l|l|}
\hline $\begin{array}{l}\text { Si } \\
\text { No. }\end{array}$ & $\begin{array}{l}\text { Maximum Size of Stone } \\
\text { Ballast } \\
\mathrm{mm}\end{array}$ & $\begin{array}{l}\text { Cement Concrete Mix } \\
\text { by Volume }\end{array}$ & $\begin{array}{l}\text { Optimum } \\
\text { Ratio }\end{array}$ & $\begin{array}{l}\text { Expected Compressive Strength } \\
\text { After 28 Days } \\
\text { N } / \mathrm{mm}^{2}\end{array}$ \\
\hline 1 & 20 & $1: 8$ & 0.40 & 5.5 \\
\hline 2 & 20 & $1: 9$ & 0.42 & 4.9 \\
\hline 3 & 20 & $1: 10$ & 0.45 & 3.5 \\
\hline 4 & 20 & $1: 12$ & 0.48 & 3.5 \\
\hline 5 & 40 & $1: 10$ & 0.48 & 3.5 \\
\hline 6 & 40 & $1: 12$ & 0.50 & 2.6 \\
\hline Note: The values given in this table are only for guidance and shall be checked in situ with actual mix. \\
\hline
\end{tabular}

The ratio 1:8 for cement aggregate is taken for 1 part of cement and 8 parts of coarse aggregate is used. In the mining process of samples Limestone Powder Waste (LPW), cement contents and coarse aggregate are placed in a concrete mixing plate and hand mixed very well for 5-7 mixes. It is observed that as the limestone powder is added. The water absorption is more means heat of hydration is more compared to normal reaction of cement. Afterwards, the fresh mixes are fed into steel moulds. The total numbers of samples prepared are 50.

\section{Samples}

$1^{\text {st }}$ Variation

$2^{\text {nd }}$ Variation

$3^{\text {rd }}$ Variation

$4^{\text {th }}$ Variation

$5^{\text {th }}$ Variation

Table 3: (VARIATION OF CUBES)

\begin{tabular}{|l|l|l|l|l|}
\hline Mixes & $\begin{array}{l}\text { Cement } \\
(\mathbf{K g})\end{array}$ & $\begin{array}{l}\text { Aggregate } \\
(\text { Kg) }\end{array}$ & $\begin{array}{l}\text { Limestone } \\
\text { Dust } \\
(\mathbf{K g})\end{array}$ & W/C Ratio \\
\hline Mix1 & 0.675 & 5.4 & 0.00 & 0.40 \\
\hline Mix2 & 0.642 & 5.4 & 0.033 & 0.40 \\
\hline Mix3 & 0.609 & 5.4 & 0.066 & 0.40 \\
\hline Mix4 & 0.576 & 5.4 & 0.099 & 0.40 \\
\hline Mix5 & 0.543 & 5.4 & 0.132 & 0.40 \\
\hline
\end{tabular}

Table 4: (VARIATION OF CYLINDERS)

\begin{tabular}{|l|l|l|l|l|}
\hline Mixes & $\begin{array}{l}\text { Cement } \\
(\text { Kg) }\end{array}$ & $\begin{array}{l}\text { Aggregate } \\
(\text { Kg) }\end{array}$ & $\begin{array}{l}\text { Limestone } \\
\text { Dust } \\
(\text { Kg) }\end{array}$ & W/C Ratio \\
\hline Mix1 & 1.06 & 8.4 & 0.00 & 0.40 \\
\hline Mix2 & 1.007 & 8.4 & 0.053 & 0.40 \\
\hline Mix3 & 0.954 & 8.4 & 0.106 & 0.40 \\
\hline Mix4 & 0.901 & 8.4 & 0.159 & 0.40 \\
\hline
\end{tabular}




0.212

0.40

Table 3 and 4 shows the number of mixes done and samples prepared for the corresponding compression strength, split tensile strength and unit weight test. The steel mould of cube is completely filled with concrete mixes using mixture proportions given in Table 3 and 4 . The initial depth of mould is approx $150 \times 150 \mathrm{~mm}$. Minimum amount of compaction is done because of the cement flow through the coarse aggregate may coagulate at the bottom of mould. After casting of samples they are removed from the steel mould. No damage is observed on the samples after demoulding. All blocks are cured by placing them in gunny bags and by sprinkling water on them for at least 3 times per day as mentioned in IS code 12727:1989 No-Fines Concrete cured for 28 days.

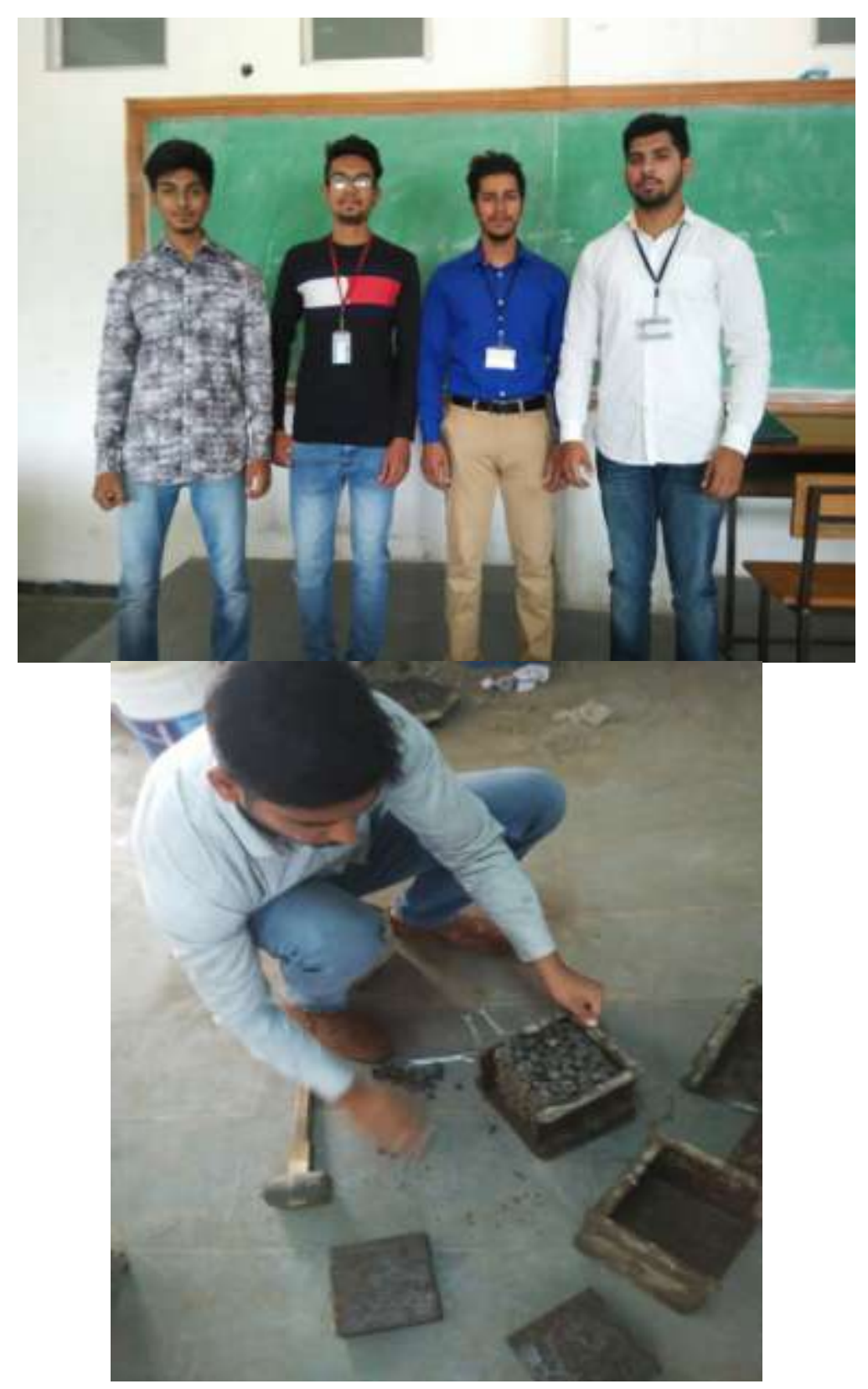



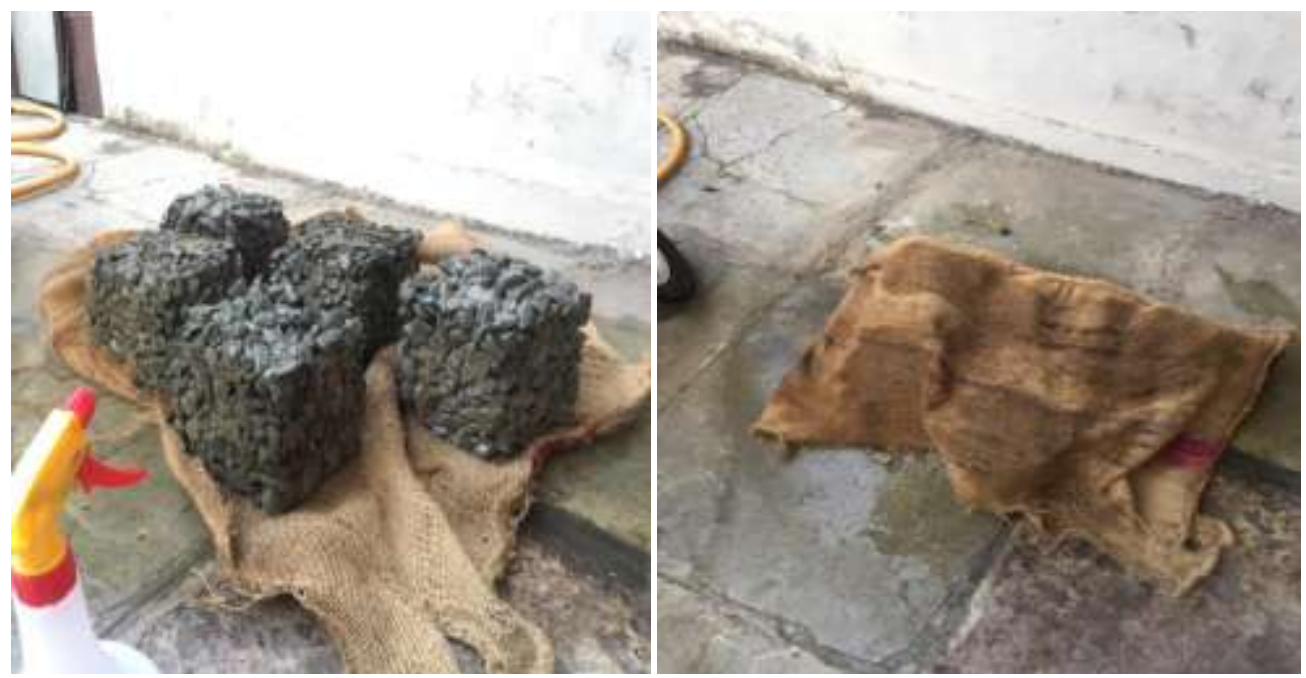

Testing Procedure

Testing - Methods The series of tests are done according to IS code 12727:1989 to know the water absorption, unit weight, compressive strength, split tensile strength values of samples.

After 28 days of curing, samples are tested for water absorption and are removed from gunny bags. The surface is cleaned by cloth to remove water droplets and weighted as soon as possible.

The brick samples are cooled at room temperature up to $27^{\circ} \mathrm{C}$ and placed in an oven at $105^{\circ} \mathrm{C}$ and taken out from oven and again weighted.

The compressive strength of brick samples is measured by compression test machine by compression testing machine which is manually testing machine manually pressure applied by hydraulic handle.

The compression load is applied on the face and base of the concrete cube having dimensions $150 \times 150 \mathrm{~mm}^{2}$. The compression strength is determined by dividing the maximum load with the applied load area of concrete cube sample.

The split tensile test is determined by placing cylinder horizontally and compressed on its circular (or) spherical surface to get the split tensile strength with support span of $300 \mathrm{~mm}$ and diameter of $150 \mathrm{~mm}$. Other 15 cylindrical samples with dimensions $300 x(150)^{2}$

$\mathrm{V}=\pi r^{2} h \rightarrow \mathrm{V}=\pi(75)^{2} \times 300 \mathrm{~mm}^{2}$

Fig 1 shows the result of compressive strength values obtained from the tests. The strength dramatically decrease for $7^{\text {th }}$ day curing and increases for $28^{\text {th }}$ day curing for every variation of sample or cube.

Fig 2 shows the result of split tensile stress values obtained from the tests.

The strength dramatically decreases for $7^{\text {th }}$ day curing and increase for $28^{\text {th }}$ day curing for every variation.

\section{COMPRESSIVE STRENGTH OF CUBES - BAR DIAGRAM}

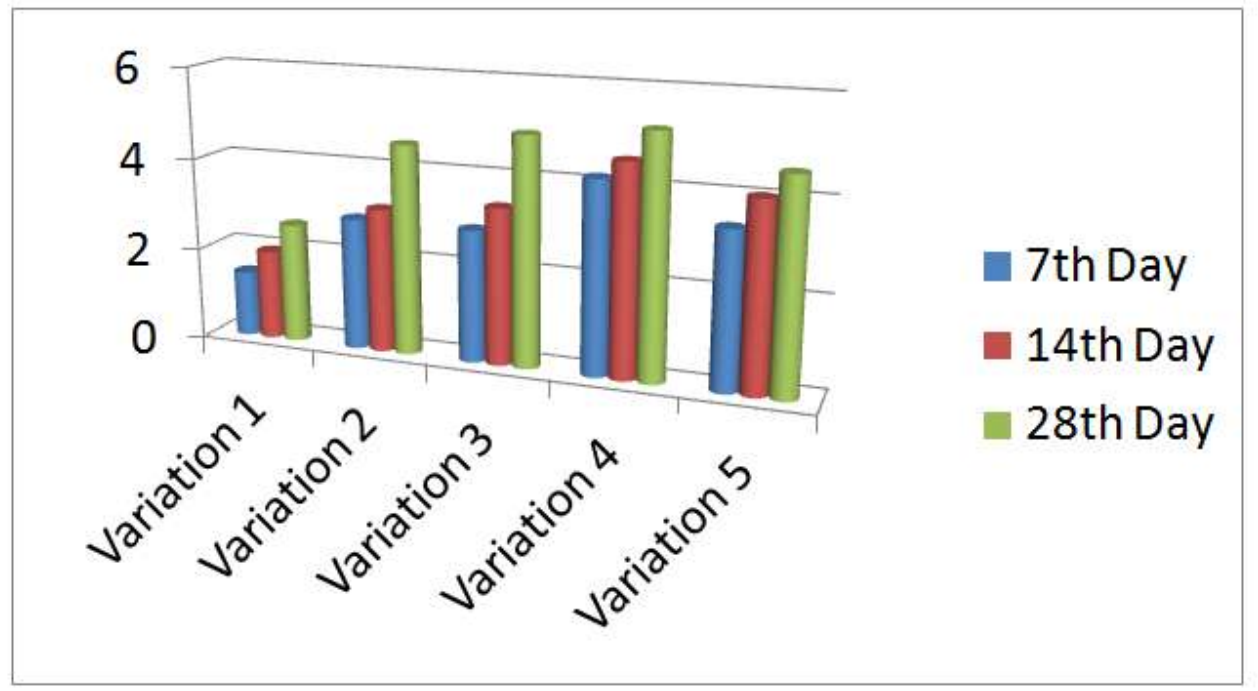




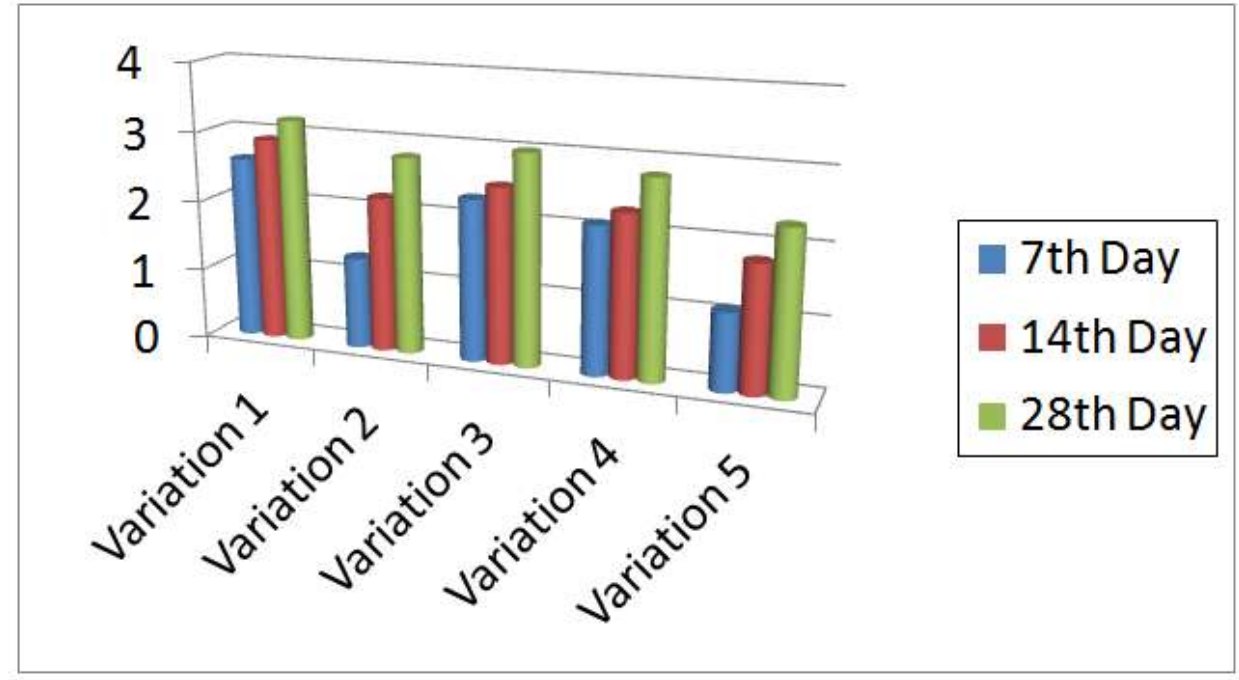

III. Conclusion

The workability of producing Limestone Powder Waste (LPW) No-Fines Concrete Brick was showed technically in this project. Based on the investigation conducted in this project, the following conclusions are

1) The Limestone Powder Waste (LPW), having $20 \%$ replacement for cement shows better results higher than other variation.

2) The No-Fines Concrete exhibited more porosity.

3) The concrete block produced comparatively lighter to conventional concrete block.

4) All bricks with 20\% LPW replacement variations satisfied the minimum compressive strength and tensile strength requirements in IS code 12727:1989.

\section{References}

[1]. $\mathrm{Li}, \mathrm{G}, \mathrm{Yu}, \mathrm{Zhao} \mathrm{Z,} \mathrm{Li} \mathrm{J,} \mathrm{Li} \mathrm{C,} \mathrm{properties} \mathrm{study} \mathrm{of} \mathrm{cotton} \mathrm{stalk} \mathrm{fiber/gypsum} \mathrm{composite,} \mathrm{cement} \mathrm{and} \mathrm{concrete} \mathrm{Research} \mathrm{2003;} \mathrm{33(1),}$ $43-6$

[2]. Galetakis M, Raka S. Utilization of Limestone dust for arfterint stone production an experiment approved minerals engg. 2004; 17:355-7

[3]. Manning D. Exploitation and use of quarry fines. Report No. 087/MIST2/DACM/01, 19 March 2004.

[4]. Aspiras FF, Manalo JR. Utilization of textile waste cuttings as building material. Journal of Materials Processing Technology 1995;48(1-4):379-84. 